\title{
Combination Extract of Lidah Mertua (Sansevieria verticilata) And Sereh (Cymbopogon nardus L.) Indifferent Drying as Anti-Microbial
}

\author{
Rizky Rahadian Wicaksono*, Eko Sulistiono \\ Environmental Healthy, Science of Healthy Faculty, UNISLA East Java, Jl. Veteran No. 53A, Lamongan, \\ Indonesia
}

*Corresponding author:

E-mail:

rahadian.rizky85@gmail.com

\begin{abstract}
Sansevieria and Cymbopogon plants are widely available in Indonesia. This plant has many benefits for us. This plant is usually used as a kitchen spice and herbal medicine because of the benefits of the plant. The purpose of this study was to determine the combination extract of Lidah Mertua (Sansevieria verticilata) and Sereh (Cymbopogon nardus L.) in different drying as anti-bacteria as anti-microbial. The method used in this research is true experimental by comparing the control class. The results obtained from this study indicate a combination of Sansevieria and Cymbopogon plant drying 48 hours more effectively inhibits the rate of microbial growth than 24 hours.
\end{abstract}

Keywords: Sansevieria, cymbopogon, anti-microbial

\section{Introduction}

The content of Cymbopogon is a mainly essential oil with 30-45\% citronella components, 6590\% geraniol, $11-15 \%$ citronellol, 3-8\% geranyl acetate, $2-4 \%$ citronellyl acetate, citral, kavikol. Geraniol is a compound consisting of 2 isoprene molecules and 1 water molecule. Geraniol can be oxidized to citral and this compound is used in ionone manufacturing plants. The high citronellal content, the high geraniol content. An important use of citronellal is for the preparation of hydroxy citronellal by hydration. Hydroxy citronellal compounds are not obtained naturally, but these compounds are the most important synthetic compounds in fragrance. The lemongrass plant contains essential oils or essential oils. The essential oil from lemongrass leaves an average of $0.7 \%$ (about $0.5 \%$ in the rainy season and can reach $1.2 \%$ in the dry season). Citronella refined oil is pale yellow. The main active ingredients produced are aldehyde compounds of 30-45\%, alcohol compounds of 55-65\%, and other compounds such as geraniol, citral, nerol, metal, heptonone, and dipentena (Khoirotunnisa, 2008).

Citronellal and geraniol are compounds that are antifungal and belong to the terpenoid group which is classified as monoterpenes which can suppress the growth of pathogenic fungi. The mechanism of fragrant lemongrass essential oil compounds as an anti-fungal is to inhibit the synthesis of ergosterol (the main sterol forming fungal cell membranes) so that the membrane protein structure becomes damaged and the membrane permeability increases which will cause the death of fungal cells (Nurmansyah, 2010). The Leaves of the Mother-in-Law's Tongue contains the active compound pregnane glycoside which functions to reduce pollutants into organic acids, sugars, and amino acids, which are not harmful to humans.

The pollutants that have been reduced are around 107 pollutants including cigarette smoke, silver waste (Ag), and lead (Pb). Meanwhile, the ALA dehydrase enzyme is an enzyme that is sensitive to inhibition by lead. With the metabolic breakdown carried out by the active compound pregnane glycoside, it is considered to be able to reduce lead in the body. So that the ALA dehydrase enzyme is not inhibited and heme production returns well (Dewi \& Indri, 2012). Also, the

How to cite:

Wicaksono, R. R., \& Sulistiono. (2021). Combination extract of lidah mertua (Sansevieria verticilata) and sereh (Cymbopogon nardus L.) indifferent drying as anti-microbial. $5^{\text {th }}$ International Seminar of Research Month 2020. NST Proceedings. pages 1-4. doi: 10.11594/ nstp.2021.0901 
antioxidants present in the in-laws of the in-laws can capture free radicals in the body. Several antioxidant compounds can be found in vitamins $\mathrm{C}$ and $\mathrm{E}$ which can affect the quantity of hemoglobin and effectively fight free radicals. Vitamin $C$ is a powerful antioxidant that works by donating electrons to metal compounds and donating electrons to intracellular and extracellular biochemical reactions and can remove oxygen compounds reactive in the cell.

Based on in vitro studies, researchers looked at the effect of citral molecules found in lemongrass on normal cells and cancer cells. At a citral concentration of 1 gram of lemongrass in hot water, citral triggers apoptosis in cancer cells without affecting normal cells (Trang et al., 2020). Lemongrass plant can be used in the treatment of stroke, because based on several studies that have been done, lemongrass can inhibit platelet aggregation, anticonvulsants, lowering blood pressure, and vasorelaxants. From several studies that have been done, it is known that the lemongrass plant can be used in the treatment of stroke. This is following the opinion of Alemeida et al. (2011), that lemongrass oil can inhibit platelet aggregation, anticonvulsants, decrease blood pressure, and vasorelaxants (Dib et al., 2017). The content of compounds such as geranyl butyrate, lomonen, eugenol, metileugenol, geranial in lemongrass can prevent cancer, treat digestive disorders, lower blood pressure, detoxify, benefit the nervous system, function as an analgesic, beautify skin and women's health.

Based on several studies on the lemongrass plant, its leaf extract contains alkaloid compounds, saponins, tannins, flavonoids, phenols, and steroids that have antioxidant activity through inhibition of DPPH free radicals (2,2-diphenyl-1-picrylhydrazyl) with the best IC50 value. in the 70\% ethanol extract of $79.444 \mathrm{mg} / \mathrm{L}$ (Batubara et al., 2020). According to research resulted by Shadri, et al (2018), that the best $\mathrm{CO}$ absorption based on the hedonic organoleptic test is at a drying time of 48 hours and a temperature of $60{ }^{\circ} \mathrm{C}$.

\section{Material and Methods}

The type of research used is descriptive qualitative with true experimental methods. The design of this study used a pretest and posttest design that was compared to control.

\section{Results and Discussion}

The production of Sansevieria and Cymbopogon plant extracts under variation drying. Plant extraction was carried out by drying in an oven at the same temperature and with two different treatments. The temperature that used in this treatment is under $60^{\circ} \mathrm{C}$. The first treatment was drying the plants for 24 hours. The next treatment was drying the plants for 48 hours. The process of drying the plant can be seen Figure 1.

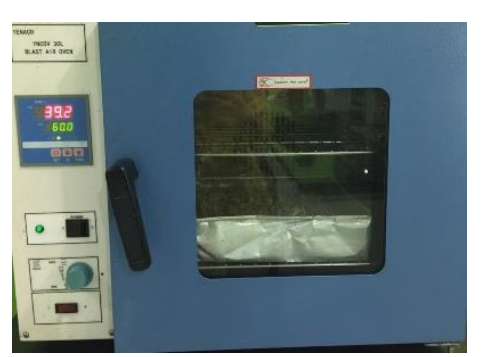

(A)

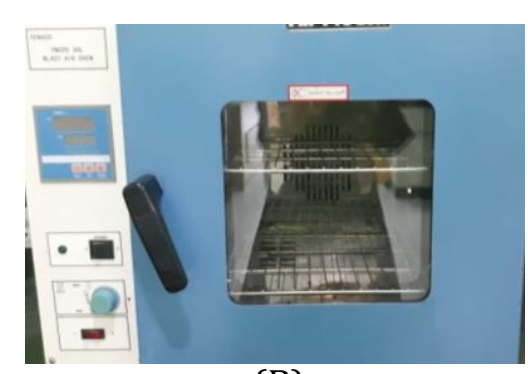

(B)

Figure 1. The process of drying of plant (A: 24 hours, B: 48 hours)

The capture of microbes is carried out in the laboratory. Microbes captured without identification. The capture of these microbes was carried out for $2 \times 24$ hours. The capture process is presented figure 2 . 


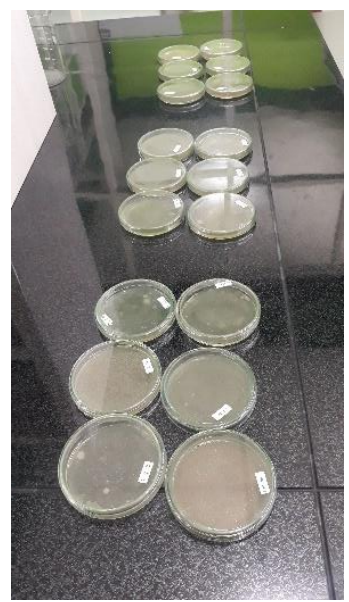

Figure 2. The capture microbes

The captured microbes were then given several aseptic treatments. The captured microbes were given a combination extract of Sansevieria and Cymbopogon with different drying durations. The results can be seen in Figure 3.
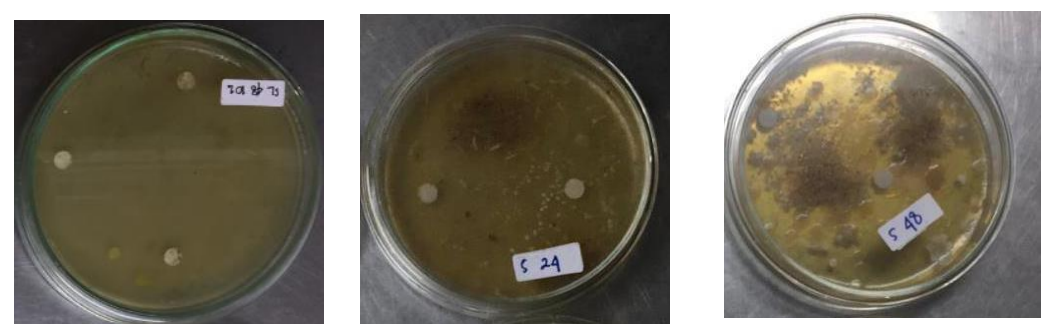

Figure 3. Given extract plant (A: Control, B: Drying 24 hours, C: Drying 48 hours

After 48 hours, observations were made of the microbial colonies that had been given the treatment. In Control, 24 hours drying and 48 hours drying had different results. The results of these differences can be presented in Figure 4 below:

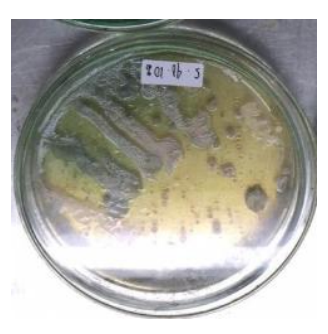

(A)

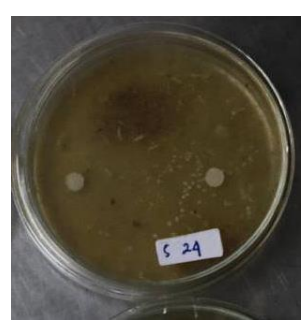

(B)

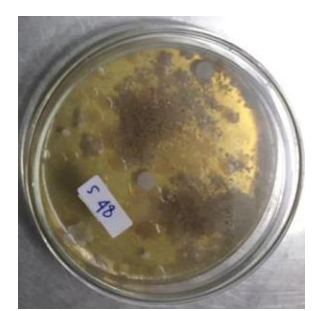

(C)

Figure 4. Result under treatment (A:Control, B: Drying 24 hours, C: Drying 48 hours)

Based on the research that has been done, it is found that the control group was overgrown with bacteria which were increasing in number every day. In the 24-hour drying group, the number of microbial colonies was slightly inhibited. In the treatment group with 24 hours drying, the number of microbial colonies was increasingly inhibited. In summary, these results can be seen in Table 1. 
Table 1. The difference in the number of microbial colonies in plant extracts with different drying times

\begin{tabular}{clc}
\hline No & \multicolumn{1}{c}{ Treatment } & Number of microbes' colonies \\
\hline 1 & Control & +++ \\
2 & 24 hours drying & ++ \\
3 & 48 hours drying & + \\
\hline
\end{tabular}

Description: +++: Microbial grow rapidly, ++: Microbial grow decreased, +: Microbial grow lowed

From the results obtained above, we know that the longer it dries, the more effective it is in inhibiting microbial growth. Citronellal and geraniol are compounds that are antifungal and belong to the terpenoid group which is classified as monoterpenes which can suppress the growth of pathogenic fungi. The mechanism of fragrant lemongrass essential oil compounds as an antifungal is to inhibit the synthesis of ergosterol (the main sterol forming fungal cell membranes) so that the membrane protein structure becomes damaged and the membrane permeability increases which will cause the death of fungal cells (Nurmansyah, 2010). According to research resulted by Shadri et al. (2018), that the best CO absorption based on the hedonic organoleptic test is at a drying time of 48 hours and a temperature of $60^{\circ} \mathrm{C}$. The ethanol extract of Sansevieria trifasciata has antimicrobial activity (Lombogia et al., 2016). This content can also reduce the number of germs so it is suitable for use as a cleaner.

\section{Conclusion}

The results of the study can be concluded that the results of this study indicate that the combined extract of Sansevieria verticilata and Cymbopogon nardus L. drying for 24 hours cannot inhibit microbial growth. While the combination extract of Sansevieria verticilata and Cymbopogon nardus L. drying for 48 hours ability inhibit microbial growth.

\section{References}

Almeida, A. L et al. (2011). Corporate reputation and the news media in Brazil in Craig Carrol (editors) corporate reputation and the news media: Agenda-setting within business news coverage in developed, emerging, and frontier markets. New York: Routledge.

Batubara, R., Surjanto, Hanum, T. S., Handika, A., \& Affandi, O. (2020). The screening of phytochemical and antioxidant activity of agarwood leaves (Aquilaria malaccensis) from two sites in North Sumatra, Indonesia. Biodiversitas, 21(4), 1588-1596. doi: $10.13057 /$ biodiv/d210440

Dewi, Y. S., \& Indri, H. (2012). Kajian efektivitas daun puring (Codiaeum varigatum) dan lidah mertua (Sanseviera tripasciata) dalam menyerap timbal di Udara Ambien. Jurnal Ilmiah Universitas Satya Negara Indonesia, 5(2), 1-7.

Dib, I., Fauconnier, M-L., Sindic, M., Belmekki, F., Assaidi, A., Berrabah, M., Mekhfi, H., Aziz, A., Bnouham, M., \& Ziyyat, A. (2017). Chemical composition, vasorelaxant, antioxidant and antiplatelet effects of essential oil of Artemisia campestris L. from Oriental Morocco. BMC Complement Altern Med, 17, 82. doi: 10.1186/s12906-017-1598-2

Khoirotunnisa, M. 2008. Aktivitas minyak atsiri daun sereh (Cymbopogon winterianus, jowitt) terhadap pertumbuhan Malassezia furfur secara in vitro dan identifikasinya. [Disertasi]. Semarang: Universitas Diponegoro.

Lombogia, B., Budiarso, F., \& Bodhi, W. (2016). Uji daya hambat ekstrak daun lidah mertua (Sansevieriae trifasciata folium) terhadap pertumbuhan bakteri Escherichia coli dan Streptococcus sp. Jurnal e-Biomedik (eBm), 4(1), 1-5. doi: https://doi.org/10.35790/ebm.4.1.2016.12230

Nurmansyah. 2010. Efektivitas minyak serai wangi dan fraksi sitronellal terhadap pertumbuhan jamur phytopthora palmivora penyebab penyakit busuk buah kakao. Buletin Penelitian, 21 (1), 43-52.

Trang, D. T., Hoang, T. K. V., Nguyen, T. T. M., Pham, C. V., Dang, N. H., Dang, H. D., Trung, N. Q., \& Nguyen, T. D. (2020). Essential Oils of Lemongrass (Cymbopogon citratus Stapf) induces apoptosis and cell cycle arrest in A549 lung cancer cells. Biomed Research International, 2020, 1-8. doi: 10.1155/2020/5924856

Shadri, S., Moulana, R., \& Safriani, N. (2018). Kajian Pembuatan Bubuk Serai Dapur (Cymbopogon citratus) dengan Kombinasi Suhu dan Lama Pengeringan. Jurnal Ilmiah Mahasiswa Pertanian, 3(1), 112-119. 